\title{
Seasonal variation in the interactions between piscivorous fish, planktivorous fish and zooplankton in a shallow eutrophic lake
}

\author{
Jacobus Vijverberg ${ }^{1}$, Maarten Boersma ${ }^{1}$, Wim L.T. van Densen ${ }^{1,2}$, Wim Hoogenboezem ${ }^{1}$, Eddy \\ II.R.R. Lammens ${ }^{1}$ \& Wolf M. Mooij ${ }^{1}$ \\ ${ }^{1}$ Limnological Institute, Tjeukemeer Laboratory, De Akkers 47, 8536 VD Oosterzee, The Netherlands; \\ ${ }^{2}$ Department of Fish Culture and Fisheries, Agricultural University, Wageningen, The Netherlands
}

Key words: food web, trophic interactions, production, consumption

\begin{abstract}
The interactions between the higher trophic levels in a shallow eutrophic lake were studied during the course of a year. Three fish species determined the main pathways of organic matter flow within the system: the predominantly planktivorous bream (Abramis brama), the obligate planktivorous smelt (Osmerus eperlanus), and the piscivorous pikeperch (Stizostedion lucioperca). Of the thirteen common zooplankton taxa Daphnia hyalina and cyclopoid copepods were utilized most by the planktivorous fish, while the large production of small cladocerans is almost left unutilized.

The seasonal variations of production and consumption are large. This is mainly affected by seasonal variation of the water temperature. The production of $\mathrm{O}+$ smelt is efficiently utilized by the pikeperch. Being the most important zooplankton consumer, as well as the most important prey group, $\mathrm{O}+$ fish plays a key role in the Tjeukemeer food web.
\end{abstract}

\section{Introduction}

Food web theory has centered around the idea of connectance, i.e. the fraction of total number of possible trophic connections actually observed (Rejmánek \& Starý, 1979). The interaction strength proposed by May (1973) also focusses on this idea. The quantities of connectance and interaction strength are easily extracted from published studies which describe food webs in natural systems (see e.g. Cohen, 1978; Pimm, 1982). In a recent evaluation Paine (1988) criticized this static approach. He has not challenged the food web theory itself, but the way natural communities have been analyzed using simple equations for connectance and interaction strength. According to Paine food web studies should focus on the dynamic, rather than on the static properties of the ecosystem, thus taking into account the spatial and temporal variations within age classes of species.

In this study we investigate the food web of lake Tjeukemeer, using Paine's approach. In previous studies on this lake Vijverberg \& van Densen (1984), Lammens et al. (1985) reported on the year to year changes in the zooplankton speciesand size composition, as well as on changes in the condition and growth of bream and pikeperch because of large variations in the stocks of $\mathrm{O}+$ fish. Production of $\mathrm{O}+$ fish may differ by two orders of a magnitude from year to year. In the years 1976-1983 it ranged from 0.12 dry 
wt $\mathrm{m}^{-2} \mathrm{yr}^{-1}$ (6 $\mathrm{kg}$ fresh wt ha- $\left.\mathrm{yr}^{-1}\right)$ to $11.7 \mathrm{~g}$ dry wt $\mathrm{m}^{-2} \mathrm{yr}^{-1}$ ( $585 \mathrm{~kg}$ fresh wt ha ${ }^{-1} \mathrm{yr}^{-1}$ ), with a geometric mean production of $2.6 \mathrm{~g}$ dry wt $\mathrm{m}^{-2} \mathrm{yr}^{-1}\left(130 \mathrm{~kg}\right.$ fresh wt ha $\left.{ }^{-1} \mathrm{yr}^{-1}\right)$.

We will focus on the seasonal changes of trophic interactions between piscivorous and planktivorous fish on the one hand and between planktivorous fish and zooplankton on the other. We select the year 1978 for the data analysis, because $\mathrm{O}+$ fish production in this year $(3.0 \mathrm{~g}$ dry $\left.w t \mathrm{~m}^{-2}\right)$ is close to the geometric mean value.

\section{Study area}

Tjeukemeer, situated in the North of the Netherlands, is a shallow (mean depth $=1.5 \mathrm{~m}$ ), eutrophic freshwater lake and has a surface area of 2150 ha. The lake is a part of an interconnected system of water bodies, which act as a reservoir for the surrounding polders. This system receives water from the near by IJsselmeer $(120000 \mathrm{ha})$ from May to September and polderwater which is rich in humic compounds in winter.
Secchi-disk depth is usually $20-35 \mathrm{~cm}$ and the algal biomass is dominated by the blue-green Oscillatoria agardhii. The littoral zone of the lake is poorly developed, representing only $1 \%$ of the lake's surface area.

\section{Methods}

\section{Zooplankton}

Zooplankton was sampled with a Friedinger closing sampler at five fixed stations at fortnightly intervals in May-September and at monthly intervals during the rest of the year. Although rotifers are often very abundant during spring, only copepods and cladocerans are important as fish food, and hence only microcrustacean zooplankton are considered. For each zooplankton species the population density and the size distribution were assessed (see Vijverberg, 1977; Vijverberg \& Richter, 1982a). Mean monthly biomass was calculated using the appropriate length-weight relationship (Table 1).

Table 1. Length-weight relations used in this study, using $\ln \mathrm{W}=\mathrm{b} \ln \mathrm{L}+\ln \mathrm{a}$. $\mathrm{W}$ is dry weight in $\mathrm{g}$, and $\mathrm{L}$ is length in $\mathrm{mm}$.

\begin{tabular}{|c|c|c|c|}
\hline Species / age group & $\mathrm{b}$ & $\ln \mathrm{a}$ & Source \\
\hline \multicolumn{4}{|l|}{ Zooplankton } \\
\hline Daphnia hyalina & 2.52 & -11.356 & Bottrell et al., 1976 \\
\hline Bosmina spp. & 2.53 & -11.104 & Bottrell et al., 1976 \\
\hline Chydorus sphaericus & 4.64 & -8.543 & Vijverberg \& Frank, 1976 \\
\hline Cyclopoid copepods & 2.40 & -11.862 & Bottrell et al., 1976 \\
\hline \multicolumn{4}{|l|}{$O+$ fish } \\
\hline smelt & 3.2 & -14.251 & Mooij own obs. \\
\hline pikeperch & 3.2 & -14.182 & Mooij own obs. \\
\hline perch & 3.2 & -13.675 & Mooij own obs. \\
\hline \multicolumn{4}{|l|}{ 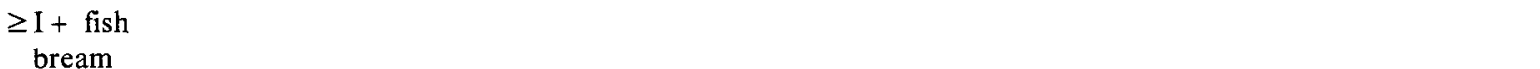 } \\
\hline sub adult & 3.0 & -12.687 & Mooij own obs. \\
\hline spring & 3.06 & -13.043 & Lammens, 1982 \\
\hline autumn & 3.10 & -13.177 & Lammens, 1982 \\
\hline \multicolumn{4}{|l|}{ pikeperch } \\
\hline spring male & 3.51 & -14.885 & van Densen \& Vijverberg, 1982 \\
\hline spring female & 3.23 & -13.057 & van Densen \& Vijverberg, 1982 \\
\hline autumn male & 3.10 & -12.140 & van Densen \& Vijverberg, 1982 \\
\hline autumn female & 2.94 & -11.176 & van Densen \& Vijverberg, 1982 \\
\hline
\end{tabular}


Monthly production was calculated using P/B ratios, which were assessed under experimental conditions in earlier studies (Vijverberg, 1980; Vijverberg \& Richter, 1982a, 1982b).

\section{Fish}

Young of the year fish $(\mathrm{O}+)$ were sampled using hoop nets from May to the first half of June, a $3 \mathrm{~m}$ trawl in the second half of June and a $5 \mathrm{~m}$ beam trawl from July onwards (van Densen, 1985). Older fish were caught using gill nets and a $5 \mathrm{~m}$ beam trawl. The number and size distribution of each species in the catch were noted. Absolute densities were estimated from the catches with the $5 \mathrm{~m}$ beam trawl, using a catching efficiency of $50 \%$ (van Densen, own obs.). Since the net efficiency for larger pikeperch is not known, pikeperch densities were estimated using the numbers of $\mathrm{O}+$ pikeperch in the previous years, combined with an instantaneous mortality rate per day (M) of $0.00055 \mathrm{~d}^{-1}$, which is a conservative estimate based on Pauly's emperical formula for the natural mortality rate in fish stocks as a function of growth parameters and water temperature (Pauly, 1980). Mean monthly biomass (B) was assessed using Ricker's (1946) formula:

$$
B=\frac{N_{O} \cdot W_{O} \cdot\left(\mathrm{e}^{(\mathrm{G}-M) \cdot t}-1\right)}{(G-M) \cdot t}
$$

where $N_{O}$ is the density and $W_{O}$ is the mean dry weight at the start of the month; the weight was computed from the size distribution using the appropriate length-weight relationship, thus taking into account seasonal changes in condition (Table 1), $G$ is the instantaneous growth rate per day, $t=30$ days, and $M$ is the instantaneous mortality rate per day; $M$ was estimated from a negative exponential curve relating numbers with time. Monthly production (P) was calculated using:

$$
P=G \cdot B \cdot t
$$

Gut contents were analyzed microscopically. The number and size distribution of each species in the gut were noted (Lammens et al., 1985; van Densen, 1985). Fish consumption was estimated using conversion factors between fish production and consumption taken from literature. Although many factors may influence this conversion (Brett \& Groves, 1979; Soofiania \& Hawkins, 1985), we did not take into account the effects of these factors, because they are very difficult to estimate quantitatively under field conditions. For $\mathrm{O}+$ fish we used a conversion of $25 \%$, which is the average of the conversion efficiency for herbivorous and carnivorous young fish reported in literature (Brett \& Groves, 1979). Consumption rates for $\geq \mathrm{I}+$ piscivorous fish were calculated using a conversion efficiency of $20 \%$ (Popova, 1978) and for $\geq \mathrm{I}+$ planktivorous fish of $12.5 \%$ (O'Grady \& Spillett, 1985).

\section{Results}

\section{Zooplankton}

About $98 \%$ of the zooplankton densities was represented by Daphnia hyalina, Bosmina coregoni, Bosmina longirostris, Chydorus sphaericus, and cyclopoid copepods. Leptodora kindtii was the largest cladoceran present, but because of its very low densities $\left(<1\right.$ ind. $\left.1^{-1}\right)$ its biomass was very low. The two Bosmina species (B. longirostris and $B$. coregoni) were lumped.

Zooplankton biomass showed a distinct seasonal pattern (Fig. 1a). During winter the zooplankton biomass was virtually zero. The cyclopoid copepod peak in May was followed by a peak of Daphnia hyalina in June. In July the small zooplankton species (Bosmina spp. and Chydorus sphaericus) exhibited their peak biomass. In autumn the large zooplankton, $D$. hyalina and cyclopoid copepods, increased again, but their biomass maxima were lower than in the preceding spring and early summer. Zooplankton production (Fig. 1b) increased steadily to reach a peak in July and thereafter decreased again. The relative importance of the species changed during the year. Production of the small species was more important in July, but 

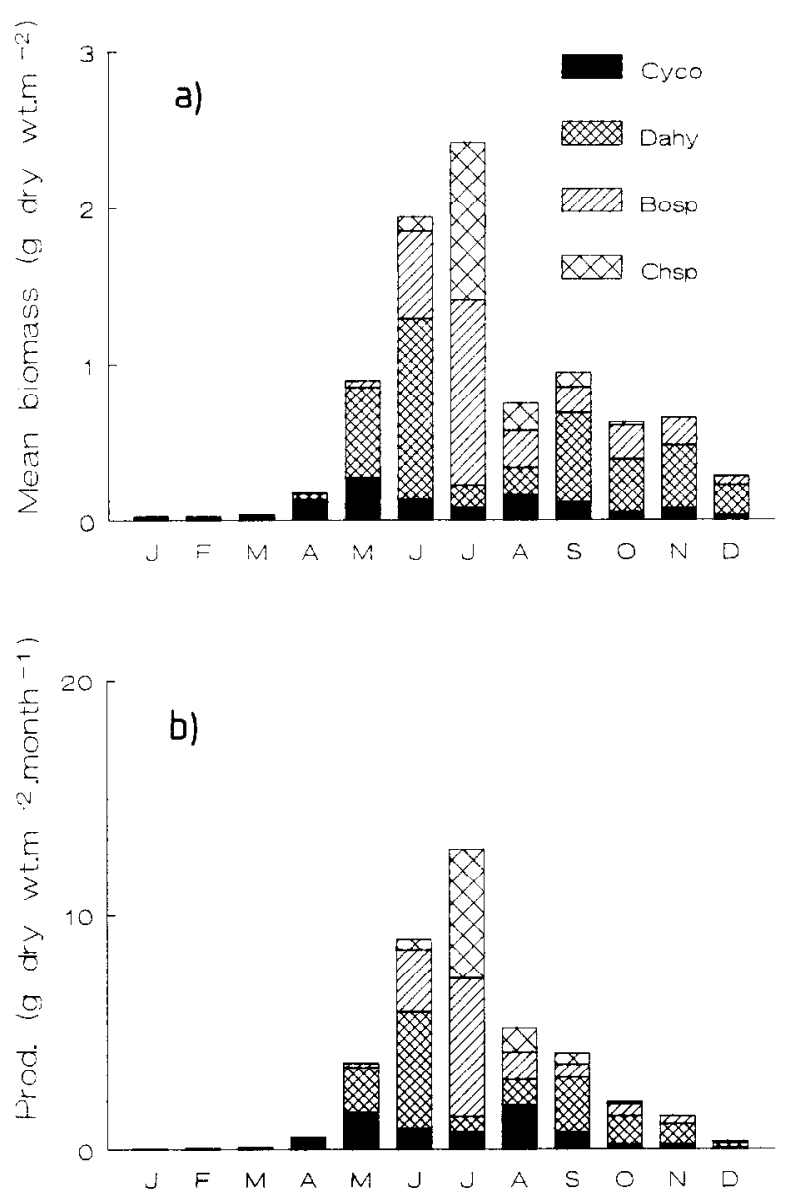

Fig. 1. Seasonal variation in zooplankton biomass and production. a. Mean monthly biomass (g dry wt $\mathrm{m}^{-2}$ ), b. Monthly production (g dry wt $\mathrm{m}^{-2}$ month $^{-1}$ ). Dahy = Daphnia hyalina, Cyco = Cyclopoid copepods, Bosp $=$ Bosmina spp., and Chsp = Chydorus sphaericus.

in spring, early summer and in autumn the large species contributed the most to the production.

\section{Fish}

The open-water fish community of the lake consists of eight species: bream (Abramis brama), white bream (Blicca björkna), roach (Rutilus rutilus), smelt (Osmerus eperlanus), pikeperch (Stizostedion lucioperca), perch (Perca fluviatilis), ruffe (Gymnocephalus cernua), and eel (Anguilla anguilla). The main pathways of organic matter flow within the community are determined by

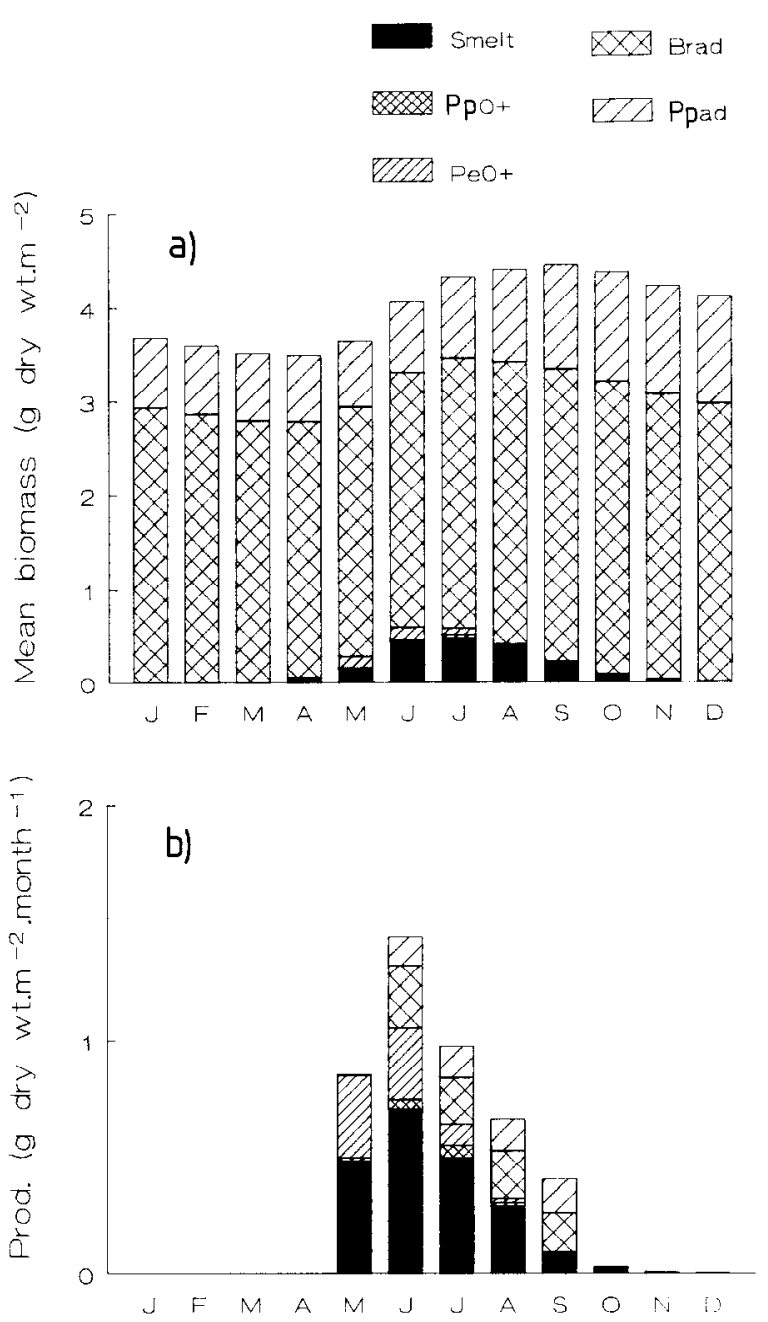

Fig. 2. Scasonal variation in fish biomass and production. a. Mean monthly biomass ( $\mathrm{g}$ dry $\mathrm{wt}^{-2}$ ), b. Monthly production (g dry wt m ${ }^{-2}$ month ${ }^{-1}$ ). SmO $+=0+$ smelt, $\mathrm{PpO}+=\mathrm{O}+$ pikeperch, $\mathrm{PeO}+=\mathrm{O}+$ perch, Brad $=\geq I+$ bream, and Ppad $=\geq I+$ pikeperch.

three groups; $\geq I+$ bream, $\geq I+$ pikeperch, and $\mathrm{O}+$ fish.

The bream population is the largest and the most stable component in the community (Fig. 2a). Its stability is based on a large number (15) of year classes. In 1978 approximately one quarter of the standing stock biomass was composed of III + (year class 1975) individuals, with individual lengths ranging from ca. $17 \mathrm{~cm}$ in spring to $22 \mathrm{~cm}$ in autumn. Production started in June and was relatively constant during the growing season (Fig. 2b). 
Pikeperch is the main predator in Tjeukemeer and $\geq \mathbf{I}+$ pikeperch is strictly piscivorous. In 1978 the standing stock biomass was composed mainly of two year classes: II + (1976), and III + (1975), with mean lengths of ca. 30 and $40 \mathrm{~cm}$ at the start of the season. Both the standing stock biomass and the production of pikeperch were relatively low compared with the biomass and production of bream (Fig. 2a, b).

$\mathrm{The} \mathrm{O}+$ fish are the most unstable component in the system. Their first appearance in April-May, as a result of spawning, depend on the ambient temperature (Mooij \& Van Tongeren, 1990). The rate of decrease in $O+$ fish biomass during August-December depends largely on the predation pressure exerted by the pikeperch (Fig. 2a). Smelt dominates the $\mathrm{O}+$ fish group, comprising $80-90 \%$ of the biomass. Total recruitment of smelt can be influenced considerably by migration of larvae from IJsselmeer (van Densen \& Vijverberg, 1982). In $1978 \mathrm{O}+$ perch and O + pikeperch also contributed substantially to the total $\mathrm{O}+$ fish biomass. The biomass of $\mathrm{O}+$ fish is low as compared with the biomass of the $\geq \mathbf{I}+$ bream. However, the production of $\mathrm{O}+$ fish is much higher than the production of bream (Fig. 2a, b). For instance the $\mathrm{O}+$ fish production in June was $70 \%$ of the total fish production, but its biomass was only $10 \%$ of the total fish biomass. This is caused by the much higher growth rates of the $\mathrm{O}+$ fish compared with the growth rates of the $\geq I+$ bream, and $\geq I+$ pikeperch. $\mathrm{O}+$ fish production was highest in June, decreasing thereafter until the end of the year.

\section{Zooplankton production and consumption by plank- tivorous fish}

From the gut content analysis of the planktivorous fish species it was observed that $\mathrm{O}+$ fish, the main tertiary producer, predates mainly on the large zooplankton species (see also van Densen, 1985). Usually the large prey species make up more than $95 \%$ of the fish diet. Only when the biomass of the large species in the environment is very low (July) are the small species also eaten considerably (ca. $40 \%$ ). $\geq \mathrm{I}+$ bream also feeds size selectively on the large zooplankton species, but its feeding behaviour differs. Bream larger than $15 \mathrm{~cm}$ are filter feeders, whereas smaller bream are generally particulate feeders (Lammens, 1984). The size selection of the filter feeding bream depends primarily on the mesh size of the branchiospinal system of the fish, which increases with increasing fish size (Lammens \& Hoogenboezem, in press). Moreover the mean proportion of benthic cladocerans and larval chironomids on biomass basis in the bream's diet is ca. $50 \%$, because large bream regularly switch to benthic feeding. This different feeding behaviour resulted in a different consumption pattern of the zooplankton of the $\mathrm{O}+$ fish and $\geq \mathrm{I}+$ bream.

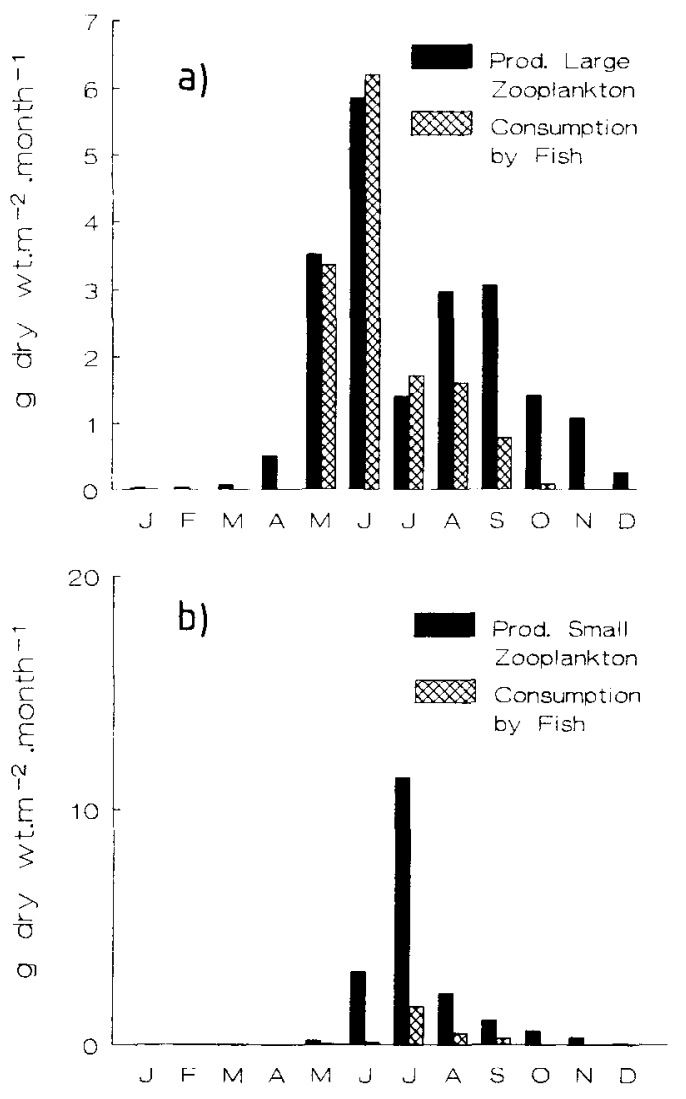

Fig. 3. Seasonal variation in the production of the zooplankton ( $\mathrm{g}$ dry $\mathrm{wt} \mathrm{m}^{-2}$ month $^{-1}$ ), and the total fish consumption (g dry wt $\mathrm{m}^{-2}$ month $^{-1}$ ). a. Production and consumption by fish of large zooplankton (D. hyalina and cyclopoid copepods), b. Production and consumption by fish of small zooplankton (Bosmina spp. and Chydorus sphaericus). 


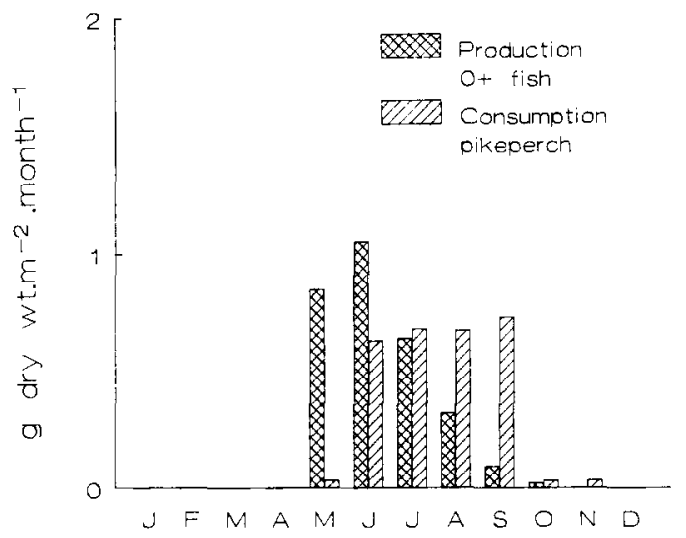

Fig. 4. Seasonal variation in the total production of $\mathrm{O}+$ fish (g dry wt $\mathrm{m}^{-2}$ month $^{-1}$ ) and the consumption by pikeperch (g dry wt $\mathrm{m}^{-2}$ month $^{-1}$ ).

In June $\mathrm{O}+$ fish only rarely fed on $D$. hyalina, whereas $\geq \mathrm{I}+$ bream fed almost exclusively on D. hyalina at that time.

During the growth season almost the entire production of the large zooplankton was eaten by the planktivorous fish (Fig. 3a), in contrast with a very small proportion of the small zooplankton production that was consumed (Fig. $3 \mathrm{~b}$ ).

\section{Planktivorous fish production and consumption by piscivorous fish}

During winter and spring, $\geq \mathrm{I}+$ pikeperch fed predominantly on I + fish, and occasionally also on II + fish. Larger prey cannot be handled by the $30-40 \mathrm{~cm}$ long predators. From June onwards pikeperch fed on the freshly recruited $\mathrm{O}+$ fish. Gut contents analysis does not indicate selection for certain fish species, and hence smelt which was most abundant was also eaten most often. In the first part of the growing season (May-June) pikeperch consumed only a small part of the $\mathrm{O}+$ fish production, later in the year, however, the consumption of pikeperch exceeded the production of $\mathrm{O}+$ fish (Fig. 4).

\section{Discussion}

On an annual basis planktivorous fish consumed $40 \%$ of the total zooplankton production. This may seem low, but the food chain efficiency is much higher if only the large zooplankton is taken into account; $70 \%$ of the large zooplankton production is consumed by planktivorous fish. Since $\geq \mathrm{I}+$ bream is not eaten by II + and III + pikeperch the food chain efficiency of pikeperch consumption is only moderate. But the efficiency is very high if only $\mathrm{O}+$ fish are taken into account, since the $\mathrm{O}+$ production eaten by pikeperch is ca. $95 \%$ (Fig. 5).

Smelt only rarely fed on $D$. hyalina in June, although the biomass of this prey is considerable at that time, and from mid June onwards no morphological limitations exist to prevent consumption of even the largest $D$. hyalina present. We cannot explain this, but it could well be related to the earlier feeding history, namely feeding on copepods (Furnass, 1979). This not feeding on $D$. hyalina by $\mathrm{O}+$ smelt in June is offset by the high predation pressure of $\geq \mathrm{I}+$ bream on $D$. hyalina; almost $100 \%$ of the bream diet consists of $D$. hyalina, which results in a consumption of almost the entire production of large zooplank-

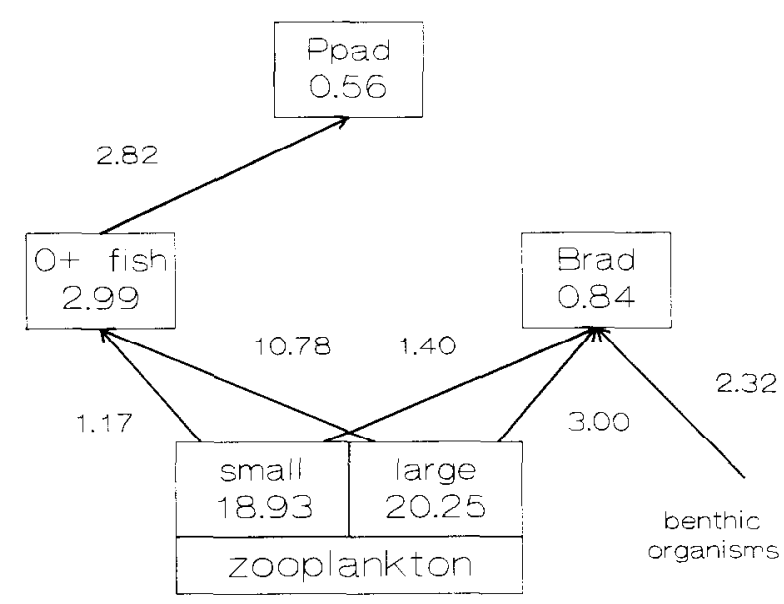

Fig. 5. The Tjeukemeer foodweb in 1978. Production (within squares), and consumption (next to arrows) of the most important groups (g dry wt $\mathrm{m}^{-2}$ year $^{-1}$ ). Ppad $=\geq \mathrm{I}+$ pikeperch, Brad $=\geq \mathbf{I}+$ bream, $\mathrm{O}+$ fish $=$ Total of $\mathrm{O}+$ smelt, $\mathrm{O}+$ pikeperch, and $\mathrm{O}+$ perch. 
ton in June. In July the $\mathrm{O}+$ fish exerts a very high predation pressure upon the large zooplankton, which wipes out almost all large zooplankton. The low biomass of large zooplankton in July causes both the $\mathrm{O}+$ fish and $\geq \mathrm{I}+$ bream to switch to feeding on small zooplankton which is consumed in substantial amounts at that time. From August onwards the production of the large zooplankton is higher than the consumption of the planktivorous fish, and this production is thought to be lost for the next trophic level. During 1978 the size of the $\mathrm{O}+$ fish stock was moderate, and consequently the predation pressure on the zooplankton was moderate too. In years when the $\mathrm{O}+$ fish stock is larger, the large zooplankton will be reduced to low levels during July-September, and a greater part of the small species will be utilized by the $\mathrm{O}+$ fish (van Densen, 1985). Hence, a low utilization of the small zooplankton species by fish is characteristic of years with low or moderate $\mathrm{O}+$ fish stocks. Most of this small zooplankton production is probably consumed by invertebrate predators (i.e. cyclopoid copepods, Leptodora kindtii, water mites). When high $\mathrm{O}+$ fish stocks reduce the biomass of large zooplankton, large bream is forced to switch to a benthic feeding behaviour, because of its filter feeding habit and hence its relatively low ability to feed on small zooplankton (Lammens, 1984). Since the biomass of benthic invertebrates is generally low in Tjeukemeer the condition of $\geq \mathrm{I}+$ bream will deteriorate (Lammens, 1982).

At first glance there is a poor agreement between the production of $\mathrm{O}+$ fish and its consumption by pikeperch. Pikeperch consumption is too low in the beginning of the year and too high at the end. However, this does not mean that the $\mathrm{O}+$ biomass produced in the beginning of the year is lost for consumption by pikeperch, since most of the production is accumulated in $\mathrm{O}+$ fish biomass. This $\mathrm{O}+$ fish biomass is still available for the pikeperch in the autumn when $\mathrm{O}+$ fish production is lower than the consumption by pikeperch. This conclusion is corroborated by the observation that $\mathrm{O}+$ fish biomass starts to decrease at the same time (July-August) that pike- perch consumption exceeds $\mathrm{O}+$ fish production.

It can be concluded that the seasonal variations in production and consumption are large, caused mainly by differences in the water temperature (range $1-23{ }^{\circ} \mathrm{C}$ ). Both zooplankton (Vijverberg, 1980 ) and fish growth (Mooij \& van Tongeren, 1990) are very much temperature related. Temperature also affects the spawning and recruitment cycle of the fish, and hence the time $\mathrm{O}+$ fish enters the system. Being the most important zooplankton consumer, as well as the most important prey group, $\mathrm{O}+$ fish plays a key role in the Tjeukemeer food web.

\section{Acknowledgements}

We thank Aafje Frank-Landman, Theo Frank, Bertus Lemsma, Peter MacGillavry, and Koos Swart for their assistance in the field and the laboratory, Anja van der Honig for the typing of the manuscript and Nico van Benthem for preparing the illustrations. We acknowledge Ramesh Gulati for his critical comments on different versions of the manuscript, and Onno van Tongeren for his interest and stimulating discussions.

\section{References}

Bottrell, H. H., A. Duncan, Z. M. Gliwicz, E. Grygierek, A. Herzig, A. Hillbricht-Ilkowska, H. Kurasawa, P. Larsson \& T. Weglenska, 1976. A review of some problems in zooplankton production studies. Norw. J. Zool. 24: 419-456.

Brett, J. R. \& T. D. D. Groves, 1979. Physiological energetics. In W. S. Hoar, D. J. Randall \& J. R. Brett (eds), Fish Physiology. Vol. 8. Academic Press, New York: 279-352.

Cohen, J. E., 1978. Food webs and niche space. Princeton University Press, Princeton, New Jersey, USA, 250 pp.

Densen, W. L. T. van, 1985. Feeding behaviour of major O + fish species in a shallow, eutrophic lake (Tjeukemeer, The Netherlands). Z. angew. Ichthyologie 1: 49-70.

Densen, W. L. T. van \& J. Vijverberg, 1982. The relation between $\mathrm{O}+$ fish density, zooplankton size and vulnerability of pikeperch Stizostedion lucioperca, to angling in the Frisian lakes. Hydrobiologia 95: 321-336.

Furnass, T. I., 1979. Laboratory experiments on prey selection by perch fry (Perca fluviatilis). Freshwat. Biol. 9: $33-43$. 
Lammens, E. H. R. R., 1982. Growth, condition and gonad development of bream (Abramis brama) in relation to its feeding conditions in Tjeukemeer. Hydrobiologia 95: 311-321.

Lammens, E. H. R. R., 1984. A comparison between the feeding of white bream (Blicca björkna) and bream (Abramis brama). Verh. int. Ver. Limnol. 22: 886-890.

Lammens, E. H. R. R. \& W. Hoogenboezem, in press. Diets and feeding behaviour. In I. J. Winfield \& J.S. Nelson (eds), The biology of cyprinid fishes. Chapman \& Hall Publ., London: XXX-XXX.

Lammens, E. H. R. R., H. W. de Nie, J. Vijverberg \& W. L. T. van Densen, 1985. Resource partitioning and niche shifts of bream (Abramis brama) and eel (Anguilla anguilla) mediated by predation of smelt (Osmerus eperlanus) on Daphnia hyalina. Can. J. Fish. aquat. Sci. 42: 1342-1351.

May, R. M., 1973. Stability and complexity in model ecosystems. Princeton University Press, Princeton, New Jersey, USA, pp. 235.

Mooij, W. M. \& O. F. R. van Tongeren, 1990. The growth of $\mathrm{O}+$ roach (Rutilus rutilus) in relation to temperature and size in a shallow eutrophic lake: comparison of field and laboratory data. Can. J. Fish. aquat. Sci. 47: 960-967.

O'Grady, K. T. \& P. B. Spillett, 1985. Gross nutrition and conversion efficiency of intensively and extensively reared carp (Cyprinus carpio L.). In C. B. Cowey, A. M. Mackie \& J. G. Bell (eds), Nutrition and feeding in fish. Academic press, London: 269-280.

Paine, R. T., 1988. Food webs, road maps of interactions or grist for theoretical development? Ecology 69: 1648-1654.

Pauly, D., 1980. On the interrelationships between natural mortality, growth parameters, and mean environmental temperature in 175 fish stocks. J. Cons. perm. int. Explor. Mer. 39: 175-192.
Pimm, S. L., 1982. Food webs. Chapman \& Hall, London, U.K., pp. 230.

Popova, O. A., 1978. The role of predaceous fish in ecosystems. In S. D. Gerking (ed.), Ecology of freshwater fish production. Blackwell Scientific Publ., London: 215-249.

Rejmánek, M. \& P. Starý, 1979. Connectance in real biotic communities and critical values for stability in model ecosystems. Nature 280: 311-313.

Ricker, W. E., 1946. Production and utilization of fish populations. Ecol. Monogr. 16: 374-391.

Soofiani, N. M. \& A. D. Hawkins, 1985. Field studies of energy budgets. In P. Tytler \& P. Calow (eds), Fish energetics - New perspectives. Croom Helm, London: 283-307.

Vijverberg, J., 1977. Population structure, life histories and abundance of copepods in Tjeukemeer, The Netherlands. Freshwat. Biol. 7: 579-597.

Vijverberg, J., 1980. Effect of temperature in laboratory studies on development and growth of Cladocera and Copepoda from Tjeukemeer, The Netherlands. Freshwat. Biol. 10: 317-340.

Vijverberg, J. \& Th. H. Frank, 1976. The chemical composition and energy contents of freshwater copepods and cladocerans in relation to their size. Freshwat. Biol. 6: 333-345.

Vijverberg, J. \& A. F. Richter, 1982a. Population dynamics and production of Daphnia hyalina Leydig and Daphnia cucullata Sars in Tjeukemeer. Hydrobiologia 95: 235-259.

Vijverberg, J. \& A. F. Richter, 1982b. Population dynamics and production of Acanthocyclops robustus (Sars) and Mesocyclops leuckarti (Claus) in Tjeukemeer. Hydrobiologia 95: 261-274.

Vijverberg, J. \& W. L. T. van Densen, 1984. The role of the fish in the foodweb of Tjeukemeer, The Netherlands. Verh. int. Ver. Limnol. 22: 891-896. 